\title{
KULTUR JARINGAN CENDANA (Santalum album L.) MENGGUNAKAN EKSPLAN MATA TUNAS
}

Tissue culture of sandalwood (Santalum album L.) using node explants

\author{
Toni Herawan ${ }^{1}$, Mohammad Na'iem ${ }^{2}$, Sapto Indrioko ${ }^{2}$, dan Ari Indrianto ${ }^{3}$ \\ ${ }^{1}$ Balai Besar Penelitian Bioteknologi dan Pemuliaan Tanaman Hutan \\ Jl. Palagan Tentara Pelajar Km. 15, Purwobinangun, Pakem, Sleman, Yogyakarta, Indonesia \\ e-mail: t_herawan@yahoo.com \\ ${ }^{2}$ Fakultas Kehutanan, Universitas Gadjah Mada \\ Jl. Agro No. 1, Bulaksumur, Sleman, Yogyakarta, Indonesia \\ ${ }^{3}$ Fakultas Pertanian, Universitas Gadjah Mada \\ JL. Flora, Komplek Bulaksumur, Sleman, Yogyakarta, Indonesia
}

Tanggal diterima : 13 Juni 2015, Tanggal direvisi : 25 Juni 2015, Disetujui terbit : 9 November 2015

\begin{abstract}
The research aim is to observe tissue culture method for Sandalwood using node explants. The explants were cultured on Murashige and Skoog (MS) medium solidified with agar and supplemented with varies combination of hormones: BAP (benzyl-amino-purine), NAA (napthalene-acetic-acid), IAA (indole-acetic-acid) and Kinetin (furfuril-amino-purine) for shoot induction, multiplication and rooting. The results of study showed that the medium of $M S+1 \mathrm{mg} / \mathrm{l} B A P+0.01 \mathrm{mg} / \mathrm{lNAA}$ provided a good response for shoot induction of Sandalwood clones number A.III.4.14 at around $85 \%$. The medium of MS+0.5 mg/l BAP+0.01 mg/l NAA provided a good response for shoot multiplication of the clones number A.III.4.14 (number of shoot and shoot elongation). The rooting medium of $1 / 2 \mathrm{MS}+20 \mathrm{mg} / \mathrm{l} \mathrm{IAA+1} \mathrm{mg} / \mathrm{l} \mathrm{IAA}$ and $0.01 \mathrm{mg} / \mathrm{l} \mathrm{NAA}$ resulted rooting percentage across the clones at around $37 \%$. The highest survival rate after acclimatization was found at clone number WS6 at around $56 \%$.
\end{abstract}

Keywords: $\quad$ Sandalwood, Santalum album, tissue culture, node explants, vegetative propagation

\begin{abstract}
ABSTRAK
Tujuan penelitian ini adalah mempelajari perkembangan dan perbanyakan Cendana menggunakan kultur jaringan mata tunas. Metode yang digunakan dalam penelitian ini adalah mata tunas yang diinkubasi dalam media Murashige dan Skoog (MS) dengan variasi penambahan Zat Pengatur Tumbuh yang terdiri atas BAP (benzyl-amino-purine), NAA (napthalene-acetic-acid), IAA (indoleacetic-acid), dan Kinetin (furfuril-amino-purine) pada tahapan induksi, multiplikasi dan perakaran. Hasil induksi kultur jaringan mata tunas menggunakan media MS $+1 \mathrm{mg} / 1 \mathrm{BAP}+0,01 \mathrm{mg} / \mathrm{l} \mathrm{NAA}$ memberikan respon terbaik pada klon A.III.4.14 dengan rerata persentase induksi 85\%. Hasil multiplikasi menggunakan media MS $+0,5 \mathrm{mg} / 1 \mathrm{BAP}+0,01 \mathrm{mg} / 1 \mathrm{NAA}$ memberikan pertumbuhan panjang tunas dan perkembangan jumlah tunas terbaik pada klon A.III.4.14. Hasil perakaran menggunakan media $1 / 2 \mathrm{MS}+20 \mathrm{mg} / 1 \mathrm{IBA}+1 \mathrm{mg} / 1 \mathrm{IAA}$ dan $0,01 \mathrm{mg} / \mathrm{l} \mathrm{NAA}$ diperoleh rerata induksi perakaran dari seluruh klon yang diuji sebesar 37\%. Hasil aklimatisasi di rumah kaca menunjukkan bahwa klon WS 6 memberikan respon persen tumbuh tertinggi sebesar 56\%.
\end{abstract}

Kata kunci: Cendana, Santalum album, kultur jaringan, mata tunas, pembiakan vegetatif

\section{PENDAHULUAN}

\section{Cendana (Santalum album L.)}

tumbuh secara alami di Indonesia

khususnya di Wilayah Nusa Tenggara
Timur (NTT) dimana jenis ini merupakan salah satu dari 22 jenis dari genus santalum yang ada di dunia (Waluyo, 2006). Cendana merupakan salah satu 
species komersial yang sangat penting yang menghasilkan minyak santalol dari bagian kayu terasnya yang digunakan secara luas sebagai bahan baku dupa dan industri parfum (Rao dan Bapat, 1995). Minyak Cendana banyak diekspor ke Eropa, Amerika, China, Hongkong, Korea, Taiwan, dan Jepang, sedangkan kayunya untuk kerajinan seperti patung, kipas, tasbih, dan rosario yang banyak dikonsumsi di dalam negeri. Kebutuhan minyak cendana dunia diperkirakan sekitar 200 ton per tahun. Mayoritas kebutuhan disuplai dari India (100 ton), sedangkan dari Indonesia, Australia, Kaledonia Baru, dan Fiji sekitar 20 ton, sehingga masih kekurangan sekitar 80 ton per tahun.

Pemanenan cendana yang berlangsung terus-menerus tanpa diikuti penanaman yang melebihi kemampuan regenerasinya baik di NTT maupun di daerah sebaran cendana lainnya mengakibatkan potensi cendana menyusut dengan cepat. Menurut IUCN / The International Union for Conservation Nature and Natural Resourcesth (2015), Cendana adalah salah satu jenis pohon yang digolongkan ke dalam kategori langka. Hal ini menjadi indikasi bahwa penyelamatan cendana merupakan hal serius dan perlu didukung dengan teknik bududaya yang baik sebagai langkah dalam melakukan regenerasi secara masal.
Cendana dapat dibiakkan secara generatif melalui biji, akan tetapi untuk melalukan perkecambahannya memerlukan penanganan yang tepat agar dihasilkan tingkat persentase perkecambahan yang tinggi. Di samping itu, tidak seimbangnya upaya-upaya penanaman dengan cepatnya laju eksploitasi, pencurian, dan kebakaran hutan, mengakibatkan sulitnya diperoleh individu-individu dewasa yang mampu memproduksi benih pada populasi alaminya. Kalaupun ada dijumpai biji cendana, biasanya dengan kualitas dan kuantitas yang rendah.

Propagasi secara konvensional telah dilakukan diantaranya melalui stek pucuk dan stek akar, akan tetapi persen keberhasilannya masih rendah (Surata, 2003). Dewasa ini beberapa teknik alternatif propagasi tumbuhan hutan melalui kultur jaringan telah banyak dan bahkan sudah lazim digunakan. Salah satu teknik kultur jaringan yang banyak digunakan adalah melalui kultur tunas aksiler.

Kultur tunas aksiler adalah kultur jaringan yang menggunakan eksplan yang berasal dari organ tumbuhan yang berupa pucuk bagian aksiler atau mata tunas. Penggunaan mata tunas aksiler karena bagian ini termasuk bagian yang juvenil dan sel-selnya masih aktif membelah sehinga diharapkan eksplan lebih mudah diinduksi (Gunawan, 1987). Kultur mata 
tunas ini merupakan salah satu teknik invitro yang digunakan untuk perbanyakan tanaman dengan merangsang munculnya tunas-tunas aksilar dari mata tunas yang dikulturkan. Eksplan yang digunakan dalam kultur mata tunas dapat berasal dari tunas lateral, tunas samping atau bagian dari batang yang mengandung satu atau lebih mata tunas (mengandung satu atau lebih buku).

Janarthanam dan Sumathi (2011) telah melaksanakan kultur jaringan Cendana menggunakan eksplan mata tunas. Namun demikian eksplan yang digunakan diambil dari jaringan muda bibit tanaman / seedling melalui biji Cendana yang dikulturkan secara aseptic. Dalam rangka pemuliaan tanaman Cendana, teknik kultur jaringan menggunakan eksplan mata tunas yang diambil dari jaringan tanaman dewasa / pohon induk terpilih tanaman Cendana belum banyak dilakukan. Untuk itu penelitian ini dilaksanakan dengan tujuan untuk mempelajari perkembangan dan perbanyakan klon Cendana melalui teknik kultur jaringan menggunakan eksplan mata tunas yang diambil dari jaringan tanaman dewasa.

\section{BAHAN DAN METODE}

\section{A. Materi genetik}

Materi genetik yang digunakan dalam penelitian ini adalah bagian cabang dari individu-individu cendana terpilih (klon) umur 9 tahun yang tumbuh pada areal Kebun Konservasi Genetik di Watusipat, Playen, Gunungkidul. Pelaksanaan kultur jaringan cendana menggunakan mata tunas dilaksanakan di Laboratorium Kultur Jaringan Balai Besar Penelitian Bioteknologi dan Pemuliaan Tanaman Hutan (BBPBPTH) di Yogyakarta.

\section{B. Prosedur Kerja}

\section{Pengumpulan eksplan dan} sterilisasi

Cabang dari pohon induk (klon) dipotong-potong menggunakan parang dan gergaji menjadi ukuran panjang $\pm 50 \mathrm{~cm}$ dan kisaran diameter $1 \mathrm{~cm} \mathrm{-} 3 \mathrm{~cm}$. Masingmasing cabang bagian ujungnya dilapisi lilin dan diberi label menggunakan spidol permanen berdasarkan nomor pohon induk (klon) yang diambil. Untuk mengurangi penguapan selama dalam pengangkutan, cabang dibungkus pelepah pisang atau dibungkus kertas koran lalu dimasukkan ke dalam kardus. Di rumah kaca cabang dibersihkan menggunakan larutan deterjen lalu dibilas menggunakan air kran sampai bersih. Cabang yang sudah bersih direndam air kran di dalam bak plastik dengan kedalaman $4 \mathrm{~cm}$. Tiap minggu air kran diganti dan cabang diamati pertumbuhan dan perkembangan tunasnya. 
Setelah tunas umur 8 minggu dapat digunakan sebagai sumber eksplan.

Eksplan mata tunas yang telah tumbuh dengan kisaran panjang 2,5 $\mathrm{cm}-$ $3,5 \mathrm{~cm}$ direndam dalam larutan fungisida konsentrasi 1 g/l selama 15 menit dan dibilas menggunakan aquadest sebanyak 3 kali. Selanjutnya eksplan direndam kembali dalam larutan diterjen selama 15 menit dan dibilas menggunakan aquadest sebanyak 3 kali. Di dalam laminar eksplan direndam larutan ethanol $70 \%$ selama 1 menit dan dibilas menggunakan aquadest steril sebanyak 3 kali. Selanjutnya eksplan direndam larutan Sodium hypochlorite (NaClO) 2\% selama 10 menit, dan dibilas aquadest steril sebanyak 3 kali.

\section{Pertumbuhan dan perkembangan eksplan}

Setelah disterilisasi, eksplan yang sudah dipotong-potong masing-masing diinokulasi ke dalam media MS (Murashige dan Skoog) yang telah ditambahkan zat pengatur tumbuh / hormon dengan kombinasi konsentrasi 1 $\mathrm{mg} / \mathrm{l}$ benzyl-amino-purine (BAP) dengan 0,01 mg/1 napthalene-acetic-acid (NAA) untuk pertumbuhan dan perkembangan awal eksplan (Herawan, 2012).

\section{Multiplikasi dan perpanjangan tunas}

Mata tunas yang telah tumbuh dan berkembang di dalam media induksi selama 4 minggu selanjutnya dipangkas dan dipindahkan ke dalam media MS yang telah ditambahkan hormone dengan kombinasi konsentrasi 0,5 mg/1 BAP dengan 0,01 mg/l NAA untuk memacu pertumbuhan tunas majemuk (Herawan, 2012). Setiap 3-4 minggu kultur harus dipindahkan ke dalam media baru dengan kombinasi dan konsentrasi hormon yang sama.

\section{Perakaran}

Tunas aksilar yang terbentuk dari hasil multiplikasi dan perpanjangan tunas selanjutnya dipisahkan dan langsung ditanam pada media pengakaran. Media untuk perakaran adalah $1 / 2 \mathrm{MS}+20 \mathrm{mg} / \mathrm{l}$ indole-butyric-acid (IBA) $+1 \mathrm{mg} / \mathrm{l}$ indoleacetic-acid (IAA) + 0,15 furfuryl-aminopurine (Kinetin). Pada media tersebut ditambahkan gula pasir masing-masing sebanyak 20 g/l dan agar 6-8 g/l. Media yang sudah ditanami eksplan diinkubasi dalam ruang kultur dengan kondisi terang pada suhu $22^{\circ} \mathrm{C}-26^{\circ} \mathrm{C}$, kelembaban antara $60-70 \%$ dan intensitas cahaya 1000-3000 lux dibawah rak-rak kultur dengan penyinaran lampu selama $16 \mathrm{jam} / \mathrm{hari}$.

\section{Aklimatisasi}

Plantlet hasil perakaran selanjutnya di aklimatisasi di dalam rumah kaca. Media yang digunakan adalah campuran volume top soil, pupuk organik,dan pasir, dengan perbandingan $2: 2: 1$. Untuk 
menjaga agar kondisi lingkungan tetap stabil selama aklimatisasi, plantlet yang sudah di tanam dalam polybag selanjutnya di sungkup menggunakan plastik bening dan diisolasi di rumah kaca yang sudah dilengkapi dengan fasilitas pengkabutan (fogging system).

\section{Rancangan Penelitian dan \\ Pengamatan}

Dalam penelitian kultur jaringan cendana ini tahapan penelitian dilakukan melalui induksi, multiplikasi, perakaran, dan aklimatisasi. Pada tahap induksi dan multiplikasi rancangan penelitian yang digunakan adalah Rancangan Acak Lengkap (RAL) faktor tunggal (klon cendana) dengan model matematis sebagai berikut :

$$
\begin{aligned}
& \mathrm{Y}_{i j}=\mu+\mathrm{B}_{i}+\varepsilon_{i j k} \\
& \text { dimana : } \\
& \mathrm{Y}_{i j} \quad=\text { variabel yang diamati } \\
& \mu \quad=\text { nilai rerata populasi } \\
& \mathrm{B}_{i} \quad=\text { efek klon cendana ke- } i \\
& \varepsilon_{i j k} \quad=\text { galat percobaan }
\end{aligned}
$$

Parameter yang diukur pada tahap induksi dan multiplikasi meliputi:

\section{Panjang tunas}

Pengamatan panjang tunas diukur dari ujung tunas aksiler sampai ujung tunas dengan satuan sentimeter $(\mathrm{cm})$.

\section{Jumlah Tunas}

$$
\text { Pengamatan dilakukan terhadap }
$$
pembentukan tunas majemuk. Tunas yang tumbuh dihitung jumlah tunasnya. Untuk tahap perakaran, parameter yang diukur adalah pertumbuhan akar melalui penghitungan jumlah akarnya.

\section{Analisis Data}

Data yang diperoleh diuji secara statistik dengan analisis varians pada tingkat kepercayaan 95\%, dan apabila terdapat perbedaan nyata pada perlakuan maka dilanjutkan dengan uji DMRT untuk menguji perbedaan dari masing-masing perlakuan.

\section{HASIL DAN PEMBAHASAN}

\section{A. Rendaman Cabang}

Pada umumnya materi vegetatif (eksplan) yang berasal dari pohon induk tidak diambil secara langsung, akan tetapi eksplan yang digunakan sebagai bahan kultur jaringan berasal dari terubusan dari stek, cangkok, atau dari rendaman cabang seperti yang digunakan pada tanaman Cendana dalam penelitian ini.

Teknik rendaman cabang (branch soaked in water) adalah teknik dimana cabang-cabang dengan ukuran panjang \pm $50 \mathrm{~cm}$ dan diameter $1-3 \mathrm{~cm}$ yang diambil dari pangkal pohon kemudian diisolasi di rumah kaca dengan kondisi suhu, kelembaban dan intensitas cahaya yang stabil dan terkontrol. Setelah direndam selama 2 minggu umumnya tunas-tunas muda yang juvenil akan mulai tumbuh dan berkembang (Gambar 1). Setelah $4-8$ 
minggu kondisi terubusan sudah kuat, ukuran panjang tunas maksimal dan tidak layu, maka tunas tersebut sudah dapat dimanfaatkan sebagai sumber eksplan.

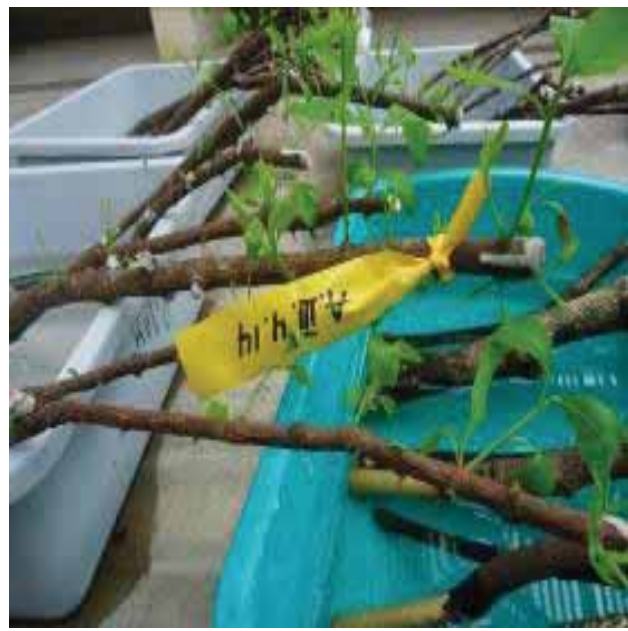

Gambar 1. Pertumbuhan tunas pada rendaman cabang cendana di rumah kaca

Hasil analisis varians rendaman cabang cendana terhadap pohon induk (klon) i menunjukkan bahwa terdapat perbedaan yang nyata diantara ke-3 klon yang diuji (Tabel 1). Hasil uji lanjut DMRT menunjukkan bahwa klon A.III.4.14 yang berasal dari Seabela (P. Rote), Nusa Tenggara Timur adalah yang terbaik dalam pertumbuhan panjang tunas pada rendaman cabang cendana (Tabel 2). Sampai dengan pengukuran minggu ke-3 rerata jumlah tunas yang diperoleh sebanyak 9,8 tunas dan panjang tunas rataratanya $2,9 \mathrm{~cm}$.

Kunci keberhasilan dalam mendapatkan eksplan yang responsif dan dapat diperbanyak dengan kultur jaringan adalah eksplan yang masih muda dan bersifat juvenile. Namun demikian daya tumbuh tunas muda akan hilang secara fisik apabila jarak antara ujung tunas dan akar semakin jauh karena pertumbuhan (George dan Sherrington, 1984). Hasil penelitian disini menunjukkan bahwa tunas juvenile dari tanaman berkayu dewasa yang akan digunakan sebagai eksplan untuk kultur jaringan cendana, dapat diperoleh dengan cara melakukan perkembangan dan pertumbuhan tunas melalui rendaman cabang. Tunas yang muncul setelah rendaman cabang dapat digunakan sebagai eksplan. Dari klon-klon tersebut di atas selanjutnya bagian pucuk tunas yang tumbuh digunakan sebagai eksplan untuk kegiatan kultur jaringan mata tunas. Teknik rendaman cabang dalam media air mengalir mampu menghasilkan materi vegetatif sebagai sumber eksplan yang bersih dan terlindung dari kotoran yang mengandung jamur dan bakteri, serta juvenile secara fisiologis (Herawan dan Husnaeni, 1996).

\section{B. Kultur Jaringan Mata Tunas}

\section{Induksi}

Ke-tiga klon yang digunakan dalam penelitian ini mampu memberikan respon induksi yang tinggi sehingga dapat digunakan sebagai sumber tunas untuk tahap berikutnya, yaitu tahap perbanyakan tunas (multiplikasi). Klon A.III.4.14 memberikan respon terbaik dengan rerata 
persen induksi mencapai 85\% (Tabel 3).

Adanya respon yang beragam dalam persen induksi memberikan indikasi adanya variasi dari ke-tiga klon yang dikulturkan. Pengaruh media kultur terhadap induksi juga menunjukkan respon yang cukup besar. Hal ini terlihat bahwa semua klon dapat diinduksi dengan baik pada media Murashige dan Skoog (MS). Hasil induksinya dapat dilihat pada Gambar 2.

Tabel 1. Hasil analisis varians panjang tunas dan jumlah tunas pada rendaman cabang cendana

\begin{tabular}{|c|c|c|c|}
\hline \multirow{2}{*}{$\begin{array}{l}\text { Sumber } \\
\text { Variasi }\end{array}$} & \multirow{2}{*}{$\begin{array}{c}\text { Derajat } \\
\text { bebas }\end{array}$} & \multicolumn{2}{|c|}{ Kuadrat Tengah } \\
\hline & & Panjang Tunas & Jumlah Tunas \\
\hline Klon & 2 & $9,667 * *$ & $44,100^{* *}$ \\
\hline Galat & 27 & 0,593 & 9,796 \\
\hline
\end{tabular}

Tabel 2. Uji lanjut DMRT panjang tunas dan jumlah tunas tiga klon cendana pada rendaman cabang

\begin{tabular}{|c|c|c|}
\hline \multirow{2}{*}{ Perlakuan } & \multicolumn{2}{|c|}{ Rerata } \\
\hline & Panjang Tunas (cm) & Jumlah Tunas \\
\hline WS28 & $0,8800 \mathrm{a}$ & $5,4000 \mathrm{a}$ \\
\hline WS6 & $1,4300 \mathrm{a}$ & $6,0000 \mathrm{a}$ \\
\hline A.III.4.14 & $2,7900 \mathrm{~b}$ & $9,3000 \mathrm{~b}$ \\
\hline
\end{tabular}

Keterangan : Nilai rata-rata dalam kolom yang diikuti huruf yang sama menunjukkan tidak ada perbedaan yang nyata pada taraf uji DMRT 5\%

Tabel 3. Hasil induksi klon cendana pada media MS menggunakan eksplan mata tunas

\begin{tabular}{|c|c|c|c|c|c|c|}
\hline No & Klon & Provenansi & $\begin{array}{l}\text { Jumlah } \\
\text { eksplan }\end{array}$ & $\begin{array}{l}\text { Jumlah } \\
\text { Induksi }\end{array}$ & $\begin{array}{c}\text { Induksi } \\
(\%)\end{array}$ & Keterangan \\
\hline 1. & A.III.4.14 & Seabela (P. Rote) & 55 & 47 & 85 & $\begin{array}{l}\text { Klon diambil dari Plot } \\
\text { konservasi genetik } \\
\text { tahun } 2005\end{array}$ \\
\hline 2. & WS6 & Pailelang (P. Alor) & 18 & 14 & 78 & $\begin{array}{l}\text { Klon diambil dari Plot } \\
\text { konservasi genetik } \\
\text { tahun } 2002\end{array}$ \\
\hline 3. & WS28 & Pailelang (P. Alor) & 70 & 41 & 59 & $\begin{array}{l}\text { Klon diambil dari Plot } \\
\text { konservasi genetik } \\
\text { tahun } 2002\end{array}$ \\
\hline & erata & & 47,67 & 34 & 74 & \\
\hline
\end{tabular}

\section{Multiplikasi}

Hasil analisis varians pertumbuhan tunas pada tahap multiplikasi cendana menunjukkan bahwa terdapat perbedaan yang diantara klon yang diteliti untuk jumlah dan panjang tunas (Tabel 4). Untuk mengetahui perbedaan lebih lanjut dilakukan uji DMRT sebagaimana hasilnya disajikan pada Tabel 5 .

Tabel 4. Hasil analisis varians panjang tunas dan jumlah tunas pada tahap multiplikasi kultur jaringan cendana

\begin{tabular}{cccc}
\hline $\begin{array}{c}\text { Sumber } \\
\text { Variasi }\end{array}$ & $\begin{array}{c}\text { Derajat } \\
\text { bebas }\end{array}$ & Panjang Tunas & Jumlah Tunas \\
\hline Klon & 2 & $29,585^{* *}$ & $280,254^{* *}$ \\
Galat & 27 & 0,582 & 52,607 \\
\hline
\end{tabular}

Keterangan: $* *=$ berbeda nyata pada taraf uji $1 \%$ 
Tabel 5. Uji lanjut DMRT panjang tunas dan jumlah tunas beberapa klon pada multiplikasi kultur jaringan cendana

\begin{tabular}{|c|c|c|}
\hline \multirow{2}{*}{ Perlakuan } & \multicolumn{2}{|c|}{ Rerata } \\
\hline & Panjang Tunas (cm) & Jumlah Tunas \\
\hline WS28 & $2,2286 \mathrm{a}$ & $14,7143 \mathrm{a}$ \\
\hline WS6 & $3,0000 \mathrm{~b}$ & $17,2632 \mathrm{ab}$ \\
\hline A.III.4.14 & $4,0909 \mathrm{c}$ & $20,4545 \mathrm{~b}$ \\
\hline
\end{tabular}

Keterangan : Nilai rata-rata dalam kolom yang diikuti huruf yang sama menunjukkan tidak ada perbedaan yang nyata pada taraf uji DMRT 5\%

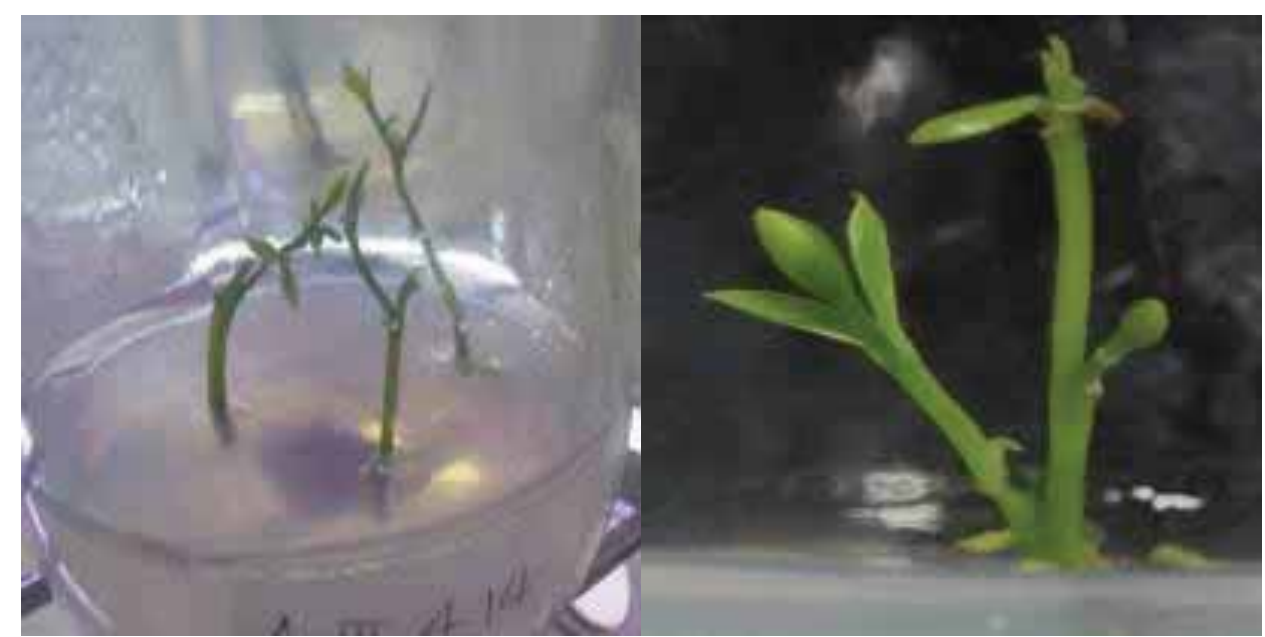

Gambar 2. Hasil induksi cendana sampai dengan minggu ke-4 dalam media MS

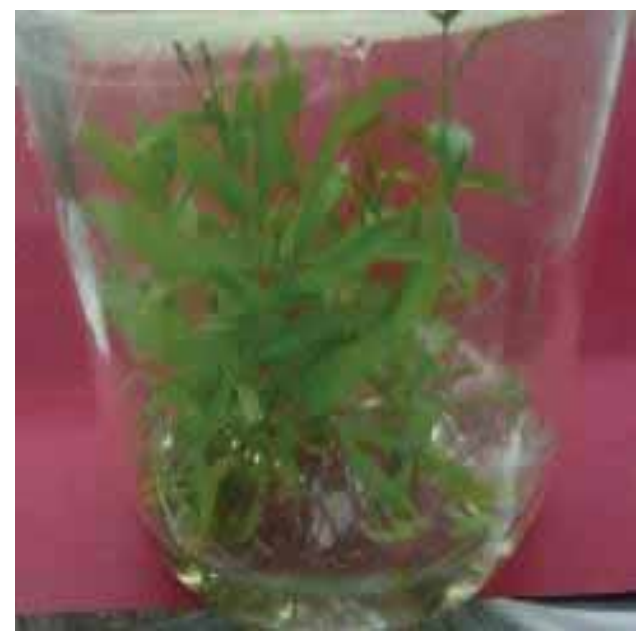

Gambar 3. Hasil multiplikasi pada kultur jaringan cendana pada umur 4 bulan setelah kultur

Hasil uji DMRT menunjukkan bahwa pertumbuhan panjang tunas terbaik pada multiplikasi cendana ditemukan pada klon A.III.4.14 sedangkan hasil terendah pada klon WS28. Perkembangan jumlah tunas pada multiplikasi kultur jaringan cendana terbanyak juga ditemukan pada klon A.III.4.14 dan paling sedikit pada klon WS28. Secara keseluruhan klon A.III.4.14 memberikan pertumbuhan 
panjang tunas dan perkembangan jumlah tunasnya yang terbaik pada multiplikasi cendana.

\section{Perakaran}

Hasil pada tahap perakaran menggunakan media 1/2 MS + $20 \mathrm{mg} / 1 \mathrm{IBA}$ $+1 \mathrm{mg} / \mathrm{l}$ IAA dan $0,01 \mathrm{mg} / \mathrm{l}$ NAA menunjukkan bahwa rerata tingkat keberhasilan mencapai 37\%. Klon WS6 memberikan respon persentase perakaran tertinggi sebesar 40\%. Gunawan (1987) menyatakan bahwa untuk media yang

Tabel 6. Hasil perakaran kultur jaringan cendana

\begin{tabular}{|c|c|c|c|}
\hline Klon & $\begin{array}{l}\text { Jumlah } \\
\text { sampel }\end{array}$ & $\begin{array}{r}\text { Jumlah } \\
\text { berakar }\end{array}$ & $\begin{array}{c}\text { Persen perakaran } \\
(\%)\end{array}$ \\
\hline A.III.4.14 & 235 & 90 & 38 \\
\hline WS6 & 125 & 50 & 40 \\
\hline WS28 & 327 & 112 & 34 \\
\hline Rerata & & & 37 \\
\hline
\end{tabular}

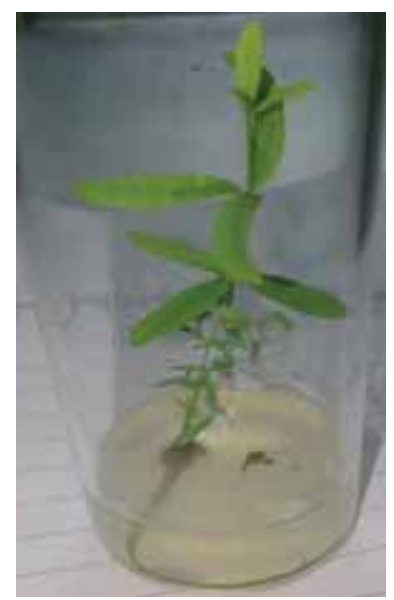

Gambar 4. Perakaran kultur jaringan Cendana menggunakan media $1 / 2 \mathrm{MS}$

Secara umum kondisi fisik yang diperlukan untuk menumbuhkan tunas cendana yang diakarkan adalah pada kisaran suhu $25^{\circ} \mathrm{C}-27^{\circ} \mathrm{C}$, kelembaban digunakan dalam menginduksi pembentukan akar penggunaan larutan garam-garam makro dengan konsentrasi rendah lebih baik dari larutan dengan konsentrasi tinggi. Pendapat ini juga didukung oleh penelitian yang dilakukan oleh Umboh (1987) yang menyatakan bahwa penggunaan media $1 / 2$ MS ditambah dengan ZPT IBA dengan konsentrasi antara 10 - $100 \mathrm{mg} / \mathrm{l}$ ditambah ZPT NAA $1 \mathrm{mg} / \mathrm{l}$ mampu menginduksi akar mencapai $70 \%$.

udara ruang tumbuh dijaga agar tetap pada 70\% (George dan Sherrington, 1984). Intensitas cahaya menurut Murashige (1974) berkisar antara $1.000-3.000$ lux.

\section{Aklimatisasi}

Hasil aklimatisasi menunjukkan bahwa klon WS6 memberikan respon tertinggi dalam pertumbuhan cendana hasil kultur jaringan yang diisolasi di rumah kaca, dengan tingkat keberhasilan 56\% (Tabel 7). Namun demikian secara umum dari ke-3 klon yang diaklimatisasi diperoleh rerata tingkat keberhasilan yang masih rendah yaitu sebesar $26,8 \%$. Hal ini diduga disebabkan formasi akar dari plantlet yang diaklimatisasi pada 
umumnya masih berupa akar tunggang sedangkan akar serabut belum terbentuk (Gambar 5a).

Herawan (2009) menyebutkan bahwa rendahnya persentase jadi plantlet saat aklimatisasi bisa disebabkan karena belum terbentuknya rambut-rambut akar pada pangkal batang plantlet cendana yang diaklimatisasi sehingga laju penyerapan unsur hara terhambat. Untuk mencapai daya tumbuh dan persen tumbuh yang optimal, plantlet yang sudah berakar umumnya harus segera dipindah atau diaklimatisasi. Pada kondisi intensitas sinar yang tinggi untuk menunjang keberhasilannya dan untuk menjaga agar suplai $\mathrm{CO}_{2}$ cukup dan menjaga kelembaban tetap tinggi, caranya dengan menyungkup plantlet menggunakan kantong plastik bening, sehingga diharapkan plantlet dapat beradaptasi dengan baik. Menurut Vertesy dan Balla (2003) bahwa kualitas bibit (ukuran dan formasi perakaran), perubahan kondisi lingkungan, kelembaban, dan pengabutan merupakan faktor yang sangat penting dalam ketahanan hidup plantlet pada kondisi di rumah kaca. Martin (2003) menyatakan bahwa peningkatan perawatan yang ditekankan pada bagaimana untuk menjaga agar tanaman yang diaklimatisasi cukup air, yaitu dengan menyediakan cukup air yang hilang akibat transpirasi. Sehingga tanaman dapat segera beradaptasi dan daun baru dapat segera tumbuh setelah 1 minggu diaklimatisasi.

Tabel 7. Hasil aklimatisasi kultur jaringan cendana menggunakan mata tunas

\begin{tabular}{lccc}
\multicolumn{1}{c}{ Klon } & $\begin{array}{c}\text { Jumlah } \\
\text { Plantlet }\end{array}$ & Jumlah yang tumbuh & $\begin{array}{c}\text { Tingkat keberhasilan } \\
(\mathbf{\%})\end{array}$ \\
\hline WS28 & 100 & 11 & 11 \\
WS6 & 72 & 40 & 56 \\
A.III.4.14 & 90 & 12 & 13,4 \\
\hline RerataTingkat keberhasilan & & & $\mathbf{2 6 , 8}$ \\
\hline
\end{tabular}

Hasil aklimatisasi menunjukkan bahwa klon WS6 memberikan respon tertinggi dalam pertumbuhan cendana hasil kultur jaringan yang diisolasi di rumah kaca, dengan tingkat keberhasilan 56\%, sedangkan hasil aklimatisasi klon A.III.4.14 tingkat keberhasilannya 13,4\% dan klon WS28 tingkat keberhasilan 11\%. Hal ini memberikan indikasi perbedaan pohon induk juga berpengaruh terhadap keberhasilan perbanyakan tanaman cendana melalui teknik kultur jaringan. Hal ini sebagaimana terlihat pada Tabel 7 bahwa walaupun berasal dari plot uji, umur tanaman dan sumber provenansi yang sama (Tabel 3), klon WS 6 dan klon WS 28 memberikan tingkat persen keberhasilan tumbuh setelah aklimatisasi yang sangat berbeda. 

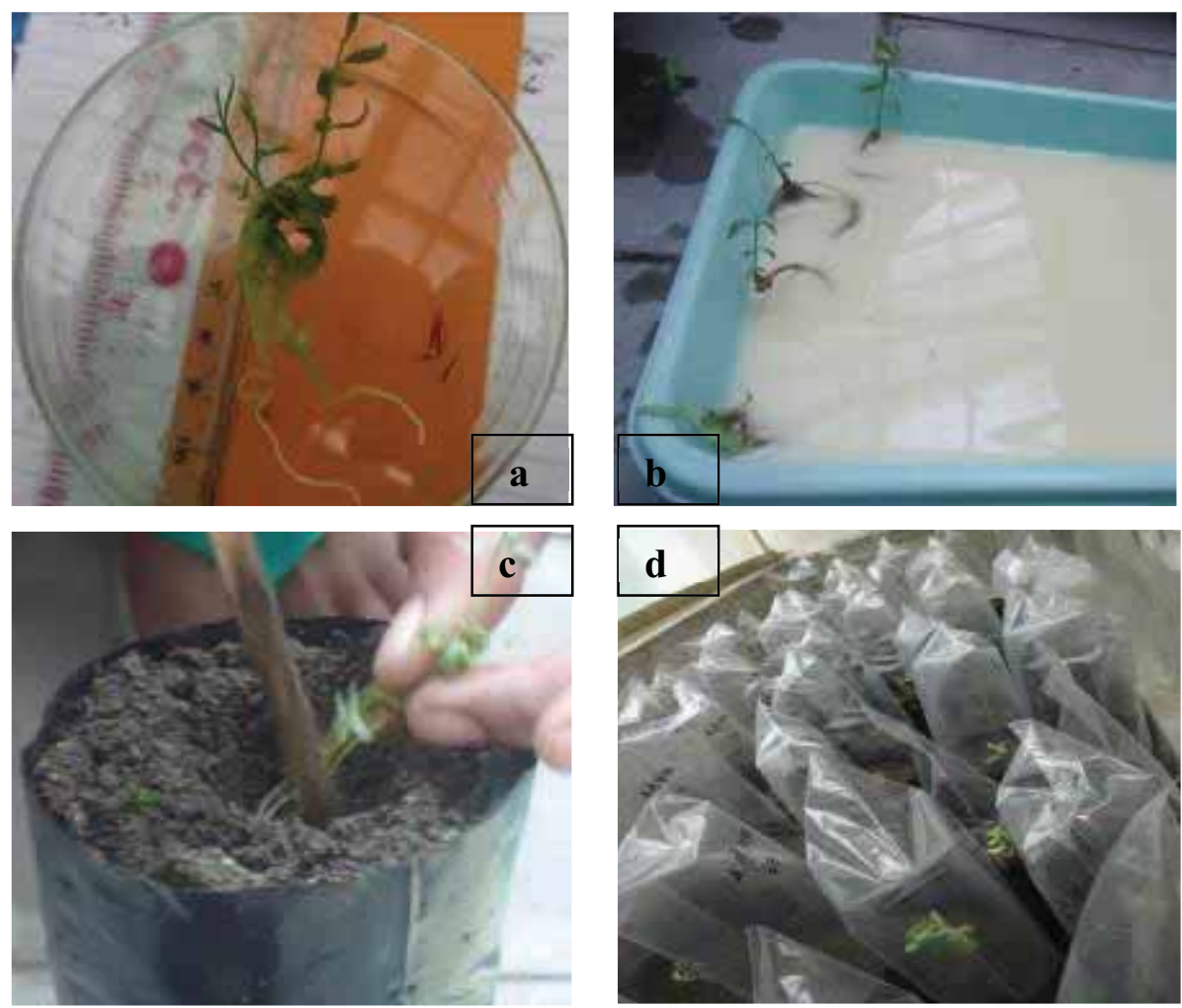

Gambar 5. Proses dan hasil aklimatisasi kultur jaringan cendana di rumah kaca (a) plantlet yamg akan di aklimatisasi; (b) sterilisasi menggunakan larutan fungisida; (c) plantlet ditanam dalam media top soil:kompos:pasir (1:1:1); (d) plantlet diaklimatisasi dengan penyungkupan di rumah kaca

\section{KESIMPULAN}

Berdasarkan hasil penelitian kultur jaringan cendana menggunakan mata tunas bahwa teknik perendaman cabang sangat menunjang dalam upaya penyediaan bahan vegetatif sumber eksplan mata tunas cendana yang juvenile/muda dan rendah kontaminasi oleh jamur dan bakteri. Penggunaan eksplan bagian mata tunas mampu memberikan jumlah tunas majemuk cendana yang banyak dan seragam. Walaupun secara umum masih menunjukkan persen perakaran dan tingkat keberhasilan tumbuh yang masih rendah setelah tahap aklimatisasi, namun demikian tanaman cendana berpotensi untuk diperbanyak dan dikembangkan secara kultur jaringan menggunakan eksplan mata tunas. Terdapat satu klon cendana (WS6) yang mampu diperbanyak secara kultur jaringan dengan tingkat keberhasilan di atas 50\%.

\section{UCAPAN TERIMA KASIH}

Penulis menyampaikan terima kasih yang sebesar-besarnya kepada Ibu Suprihati yang telah membantu peneliti dalam penyiapan media dan pengumpulan data penelitian ini. Penulis juga menyampaikan terima kasih yang sebesarbesarnya kepada Ibu Fithry Ardhany yang telah memberikan saran, masukan, dan penyempurnaan jurnal ini. 


\section{DAFTAR PUSTAKA}

Asian Regional Workshop. (1996). Conservation and sustainable management of trees. Vietnam.

Dinas Kehutanan Propinsi Nusa Tenggara Timur. (1998). Laporan inventarisasi cendana (Santalum album L.) di Pulau Timor. Dinas Kehutanan Propinsi Nusa Tenggara Timur.

FAO. (2015). Flavours and fragrances of plant origin. Sandalwood oil. Chapter 6. FAO Corporate Document Repository.

Retrieved from www.fao.org/docrep/v5350e

Gaspar, T. H., \& Coumans, M. (1994). Root formation. Physiological ecology of forest production on micropropagation of forest trees throught tissue culture. Institute for Forestry and Nature Research (IBN-DLO), Netherland.

George, E. F., \& Sherington, P. D. (1984). Plant propagation by tissue culture. Part 1. (pp. 184-382). Edington, Wilts, England: Exergetics Ltd.

George, E. F. (1993). Plant propagation by tissue culture (2nd ed)( p. 445). Edington, Wilts, England: Exergetics Ltd.

Gunawan, L. W. (1987). Teknik kultur jaringan. Laboratorium kultur jaringan tanaman, Pusat Antar Universitas (PAU) Bioteknologi, Institut Pertanian Bogor.

Harisetijono. (2003). Kebijakan pengelolaan cendana di NTT (Refleksi dan rekomendasi kebijakan pengelolaan cendana yang lestari). Promosi hasil-hasil penelitian dan temu karya cendana. Balai Litbang Kehutanan Bali dan Nusra. Kupang.

Herawan, T., \& Husnaeni, Y. (1996). Penelitian awal permudaan pohon cendana (Santalum album) menggunakan teknik rendaman cabang dalam media Air. Wana Benih,1(1). Balai Litbang Pemuliaan Benih Tanaman Hutan, Yogyakarta.

Herawan, T. (2009). Teknik Aklimatisasi Kultur Jaringan Cendana (Santalum album L.). Informasi Teknis, 7(1). ISSN: 1412-8284. Yogyakarta: Balai Besar Penelitian Bioteknologi dan Pemuliaan Tanaman Hutan.

Herawan, T. (2012). Review Kultur Jaringan Cendana (Santalum album L.). In A. Rimbawanto, B. Leksono \& A. Y. P. B. C. Widyatmoko (Eds.). Prosiding Seminar
Nasional Bioteknologi Hutan

"Bioteknologi hutan untuk produktivitas dan konservasi sumber daya hutan" Yogyakarta, 9 Oktober 2012, (pp. 65-90). Yogyakarta: Balai Besar Penelitian Bioteknologi dan Pemuliaan Tanaman Hutan. ISBN: 978-979-3666-15-0.

Mariska, I., \& Purnamaningsih, R. (2001). Perbanyakan vegetatif tanaman tahunan melalui kultur in vitro. Jurnal Litbang Pertanian, 20(1), 1-7.

Martin. (2003). High survival rates during acclimatization of micropropagated ftuit tree rootstocks by increasing exposures to low relative humidity. In A.S. Economou, P.E. Read, \& Sani-Halkidiki (Eds.). Proceeding international symposium on acclimatization and establishment of propagated plants. Macedonia, Greece.

Murashige, T. (1974). Plant propagation through tissue culture. Development of plant science, University of California, California.

Murashige, T. (1974). Plant Propagation Through Tissue Cultures. Annual Review Plant Physiology, 25(1), 135-166.

Pusat Penelitian dan Pengembangan Hutan Tanaman. (2006). Data base jenis-jenis prioritas (untuk konservasi genetik dan pemuliaan). Buku 2. P3HT, Yogyakarta.

Surata, I. K. (2003). Dukungan hasil litbang dalam penyiapan bibit dan penanaman cendana. Promosi hasil-hasil penelitian dan temu karya cendana. Balai Litbang Kehutanan Bali dan Nusra. Kupang.

The IUCN Red list of threatened species. (2015). Retrieved from www.iucnredlist.org/details/31852

Umboh, M. I. J., \& Kamil, H. (1987). Root induction of Santalum album by using IBA and NAA. Seameo-Biotrop, Bogor.

Vertesy, J., \& Balla, I. (2003). Acclimatization of woody plants under continental climatic conditions. In A.S. Economou, P.E. Read, \& Sani-Halkidiki (Eds.). Proceeding international symposium on acclimatization and establishment of propagated plants. Macedonia, Greece. 